Egyptian Journal of Aquatic Biology \& Fisheries

Zoology Department, Faculty of Science,

Ain Shams University, Cairo, Egypt.

ISSN $1110-6131$

Vol. 23(1): $151-159$ (2019)

www.ejabf.journals.ekb.eg

\title{
Effect of UV- C radiation on survival of Escherichia coli O157: H7 inoculated fish fillets from fresh water and marine sources
}

\author{
Omaima M. Ahmed and Hesham F. Amin \\ Department of Fish Processing and Technology, Faculty of Fish Resources, \\ Suez University, Egypt.
}

\section{ARTICLE INFO \\ Article History: \\ Received: Nov. 10, 2018 \\ Accepted: Jan. 28, 2019 \\ Available online: Feb. 2019}

\section{Keywords:}

Escherichia coli

O157:H7

UV-C radiation

Oreochromis niloticus

Nemipterus japonicas

\begin{abstract}
Radiation technique using UV-C was applied in this study on freshwater Nile tilapia fish (Oreochromis niloticus) and marine-water Japanese threadfin bream fish (Nemipterus japonicas) fillets injected by Escherichia coli strain O157:H7. Tilapia fish (average weight and length are $150 \pm 10 \mathrm{~g}$, $15 \pm 5 \mathrm{~cm}$, respectively) and threadfin bream (average weight and length are $120 \pm 5 \mathrm{~g}$ and $15 \pm 2 \mathrm{~cm}$, respectively) were collected from fresh fish market at Suez, Egypt. Fish samples were filleted, injected with Escherichia coli strain O157:H7, and subjected to UV treatment (15W). Samples exposed to UV irradiation (monochromatic, $253.7 \mathrm{~nm}$ ) at four different distances: 12, 24, 30 and $45 \mathrm{~cm}$. Each UV-C radiation treatment was performed for 5, 10, 15, and $20 \mathrm{~min}$. Maximum reduction in the total count of E. coli strain O157:H7 (1.82 logs CFU/g) was associated with threadfin bream marine fish samples treated at $45 \mathrm{~cm}$ for $20 \mathrm{~min}$. While in tilapia samples, count of E. coli strain O157:H7 was reduced to $1.1 \operatorname{logs}$ $\mathrm{CFU} / \mathrm{g}$ when treated at $24 \mathrm{~cm}$ for $15 \mathrm{~min}$. Therefore, this study recommends this simple method of radiation using UV-C as a successful technique to expand the safety of fish fillets from fresh water and marine sources.
\end{abstract}

\section{INTRODUCTION}

Marine and Fresh-water systems cover about three quarters of the surface of the Earth, result in a series of critical-ecosystem-services (Younis, 2018). There has been a growing recognition of the interrelationship between human health and the oceans, especially due to the increase in the development of human activities near coastal areas and their diversity (Said et al. 2006; Shreadah et al., 2006; Younis \& Nafea 2012; Younis et al., 2014; El Zokm et al., 2015; Soliman et al., 2018). This could cause risk to human health and therefore seafood contamination (Younis et al., 2018; Amin et al., 2018).

Fish filleting is the most commercial practice to process fish with the aims of adding value to the product, maintain high quality and preserve the harvested fish from potential contamination by gut, and head contents. Fish fillets are exposed to high-risk of foodborne contamination, if processed under poor hygienic measures. To reduce risks of contamination, several non-thermal physical techniques of sanitation and disinfection to food surfaces have been proposed. Ultraviolet (UV) irradiation has been recognized as one of the most important technology with promising wide applications (Sheen et al., 2012; Karlsen et al., 2015; and Freitas et al., 2015). It was 
reported used in food for inactivating foodborne bacterial pathogens (Kim et al., 2017).

Escherichia coli were usually investigated as a fecal contamination indicator to assess the cleanliness and safety of seafood (Martínez et al., 2009). Although $E$. coli O157:H7strains are not commonly associated with seafood, still some outbreaks were reported (Surendraraj et al., 2010 and Matulkova et al., 2013). Fish are very sensitive to heat, and non-thermal technologies are preferred to control seafood borne pathogens. Therefore, this study investigated the application of UV-C radiation technology under different treatment times and distances on the survival of Escherichia coli O157:H7 inoculated in fish fillets. Compare the effect of these treatments on inoculated fresh water fish (Nile tilapia) fillets versus inoculated marine fish (Japanese threadfin bream) fillets.

\section{MATERIALS AND METHODS}

\section{Fish samples}

Freshwater tilapia (Oreochromis niloticus) fish (10 kg) and marine Japanese threadfin bream (Nemipterus japonicas) fish $(10 \mathrm{~kg})$ samples were purchased from local fish market in Suez Governorate, Egypt in 2018. The average weight and length were $150 \pm 10 \mathrm{~g}$ and $15 \pm 5 \mathrm{~cm}$ for tilapia, and $120 \pm 5 \mathrm{~g}$ and $15 \pm 2 \mathrm{~cm}$ for threadfin bream, respectively. Each fish species were transported to the laboratory packed in a sterilized cooler filled with ice (at $<2^{\circ} \mathrm{C}$ ). The fillets were prepared manually $(50 \pm 1$ $\mathrm{g}$, and $38 \pm 1 \mathrm{~cm}$ ), carefully washed with tap water, and immediately prepared for the experiment.

\section{Bacterial strain}

E. coli strain O157:H7 was acquired from Ain Shams University, Microbiological Resources Center, at Cairo, Egypt. Stock cultures were sub-cultured twice into $10 \mathrm{~mL}$ of Brain Heart Infusion broth (BHI, Lab M, Neogen Company, UK), incubated at $37^{\circ} \mathrm{C}$ for $24 \mathrm{hr}$, and streaked onto Tryptic Soy Agar slants (TSA, Lab M, UK). Culture from TSA plates were streaked on Sorbitol MacConkey agar (SMAC, Lab M, Neogen Company, UK) and examined for typical colony morphology. Typical colonies confirmed by biochemical tests (indole, citrate, Methyle Red, Voges-Proskauer), API 20 E biochemical test strips (Biomerieux, France), and serological method using slide agglutination test with O157, and H7 antisera (pro-lab, USA). Then, the bacterial culture was used immediately for the preparation of the inoculum.

\section{Inoculation of fish fillets}

Population of E. coli strain O157: $\mathrm{H} 7$ at 7-8 $\operatorname{logs}$ CFU/mL was prepared from the confirmed bacteria. The inoculum was cultured in Tryptic soy broth (TSB, Lab $\mathrm{M}$, Neogen Company, UK) incubated at $35^{\circ} \mathrm{C}$ for $24 \mathrm{~h}$. Cell suspensions were centrifuged (Eppendorf, 14,000 rpm) for $10 \mathrm{~min}$ and pellet was suspended in buffered peptone water (BPW, Oxoid, UK). Bacterial cell counts were performed on TSA plated and incubated for $24 \mathrm{hr}$. at $35^{\circ} \mathrm{C}$. Fish fillets samples were cut into $5 \mathrm{~g}$ pieces and used immediately after inoculation of bacterial suspension $(1 \mathrm{ml})$ on each sample. The inoculated samples in a sterilized petri-dish were set in laboratory for 2 hours and then exposed different UV-C treatments (Chun et al., 2010).

\section{Exposure to UV-C surface irradiation}

The UV-C irradiation experiments were performed with a bench top UV reactor contained two UV lamps (each one $15 \mathrm{~W}$, monochromatic, $253.7 \mathrm{~nm}$ ). The exposure to UV light was set to $0,5,10,15$, and $20 \mathrm{~min}$ on the inoculated fish sample surface, with different exposure heights of 12, 24, 30, and $45 \mathrm{~cm}$ from UV lamp to 
the exposed fish surface. The UV lamp was turned on for at least $30 \mathrm{~min}$ before each experiment to ensure a constant UV intensity (Lee et al., 2016).

\section{Bacteriological analysis}

Inoculated samples ( $5 \mathrm{~g}$ ) were homogenized in sterile bags for $2 \mathrm{~min}$. sterile $0.1 \%$ peptone water $(45 \mathrm{ml})$, and then serial dilution in $0.1 \% \mathrm{PW}$ was conducted. Each dilution $(1 \mathrm{ml})$ were plated in triplicate on SMAC, and incubated for $24 \mathrm{~h}$. at $37^{\circ} \mathrm{C}$. Clear colonies were considered positive for $E$ coli $\mathrm{O} 157: \mathrm{H} 7$ and counted at a range of 25-250 CFU per plate.

\section{Statistical analysis}

All treatments were conducted in triplicates and bacterial counts were reported as means (log CFU/g). Analysis of variance (ANOVA) was applied on this experiment using SPSS version 12. The average log reduction was pairwise compared between treatment times and distances from the UV lamps using Tukey test with a $95 \%$ confidence level.

\section{RESULTS AND DISCUSSION}

UV-C irradiation reduced the total E. coli strain O157: $\mathrm{H} 7$ count in tilapia fish fillets as shown in Figure $(1)$. The highest reduction $(\mathrm{P}<0.05)$ of bacterial count was found of tilapia fillets located at 24 and $30 \mathrm{~cm}$ from UV lamps, respectively. The results show that the overall average counts exposed to UV-C for 5, 10, 15, and 20 min were $6.5 \pm 0.32,6.35 \pm 0.13,6.2 \pm 0.82$, and $6.4 \pm 0.57 \log$ CFU/g (Fig. 3), respectively compared to $7.3 \pm 0.1 \mathrm{log} \mathrm{CFU} / \mathrm{g}$ of non-treated control as shown in Table 1. The log reductions of E. coli strain O157: H7 were $0.8,0.95,1.1$, and 0.9 logs CFU/g, respectively.

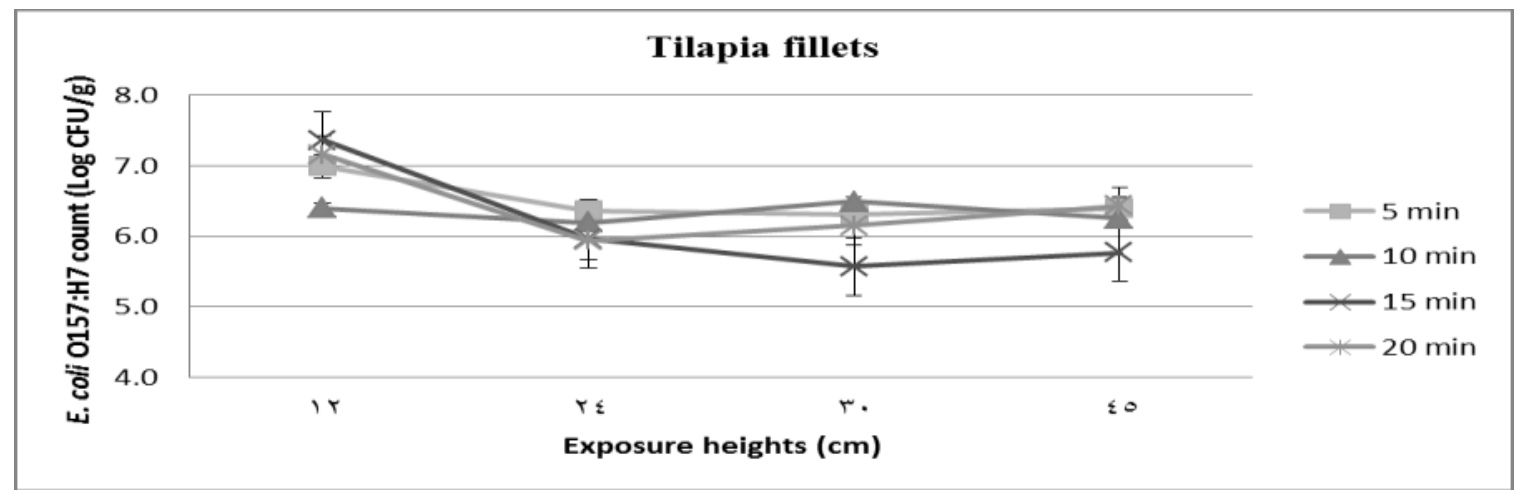

Fig. 1: Reduction of UV-C radiation on E. coli strain O157:H7 count (Log CFU/g) in Tilapia fillets at different heights $(\mathrm{cm})$.

On the other side, UV-C irradiation reduced the total count of E. coli strain O157: H7 in threadfin bream fish fillets as shown in Figure (2). The highest reduction $(\mathrm{P}<0.05)$ was found at height $45 \mathrm{~cm}$ followed by $24 \mathrm{~cm}$ from UV lamps (Fig. 2). The overall average E. coli counts of marine fillets exposed to UV-C were $6.43 \pm 1.06,5.85 \pm$ 0.37, $5.8 \pm 0.41$, and $5.38 \pm 0.30 \mathrm{log} \mathrm{CFU} / \mathrm{g}$ for 5, 10, 15, and $20 \mathrm{~min}$ (Fig.4), respectively compared with control $(7.2 \pm 0.1 \mathrm{log} \mathrm{CFU} / \mathrm{g})$ (Table 1$)$. The reductions of bacterial count were $0.77,1.35,1.4$, and $1.82 \operatorname{logs} \mathrm{CFU} / \mathrm{g}$, respectively. 
Table 1: Counts of E. coli strain O157:H7 in raw tilapia and Japanese threadfin bream fish fillets (control).

\begin{tabular}{|l|l|}
\hline Fish species & E. coli O157:H7 count $(\log$ CFU/g) \\
\hline Tilapia fillets & $7.3 \pm 0.1$ \\
\hline Japanese threadfin bream fillets & $7.2 \pm 0.1$ \\
\hline
\end{tabular}

These results (n3) were expressed as Mean \pm SD.

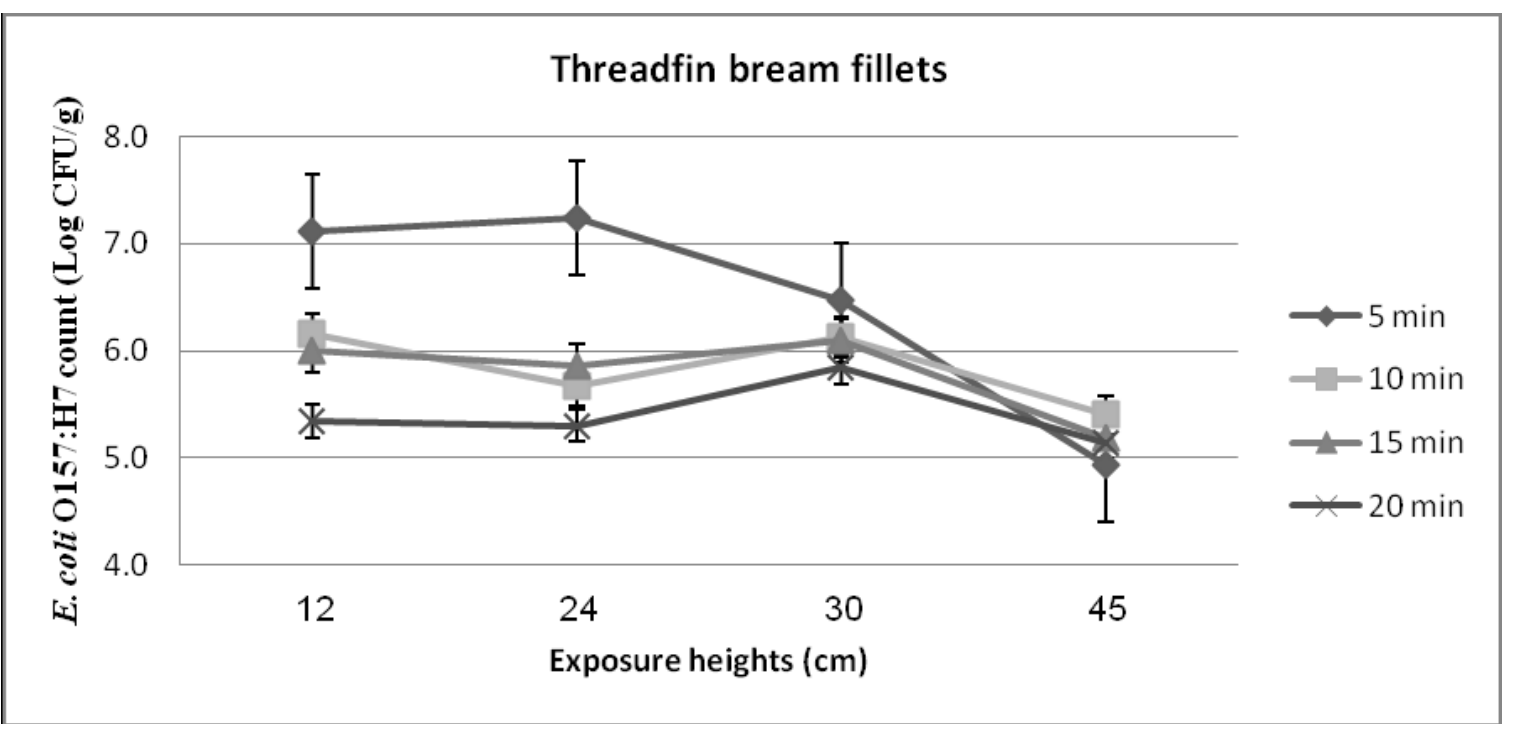

Fig. 2: Reduction of UV-C radiation on E. coli strain O157:H7 count (Log CFU/g) in threadfin bream fillets at different heights $(\mathrm{cm})$.

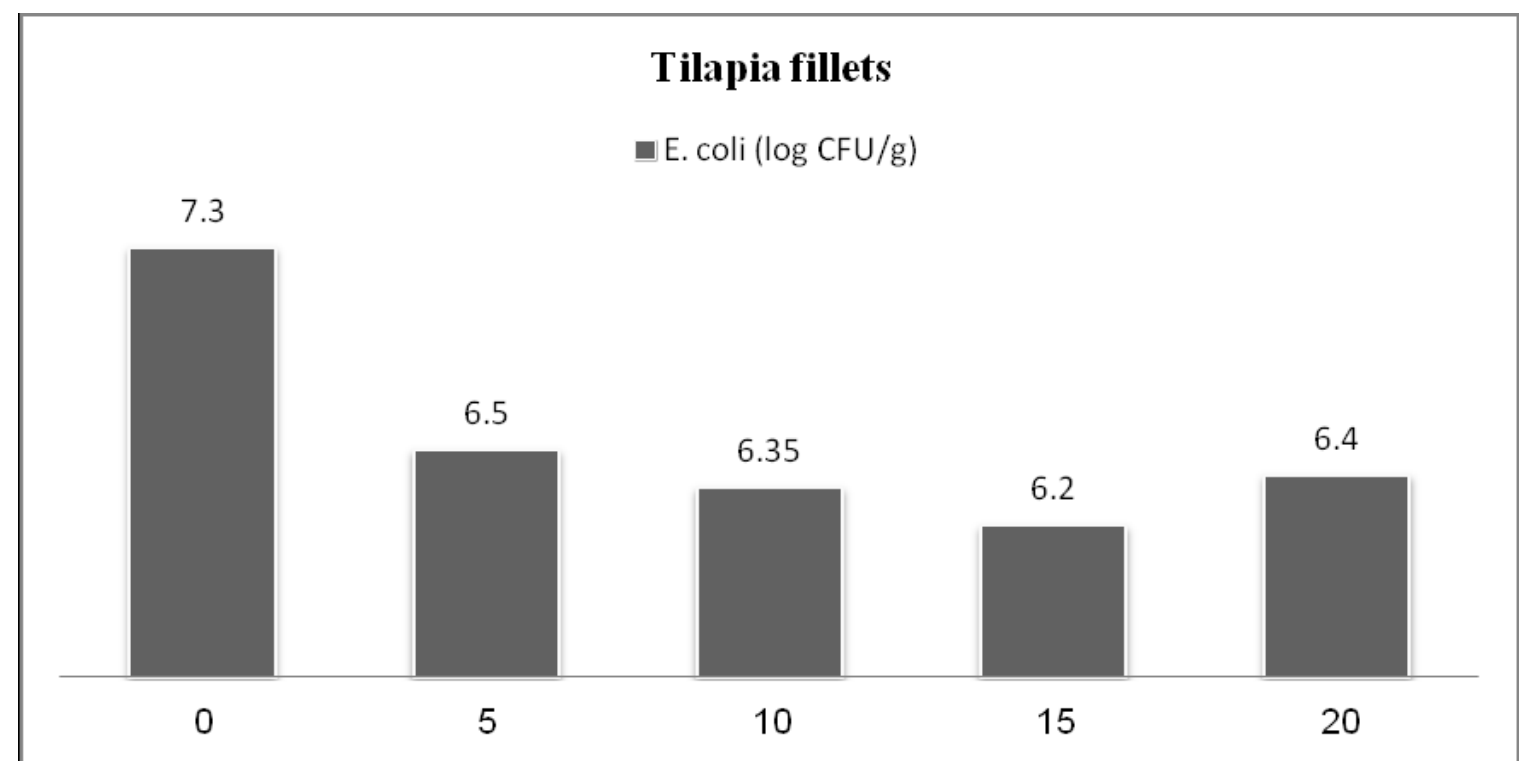

Fig. 3: Reduction rate of UV-C radiation on E. coli $\mathrm{O} 157: \mathrm{H} 7$ count (Log CFU/g) in Tilapia fish for different times (min). 


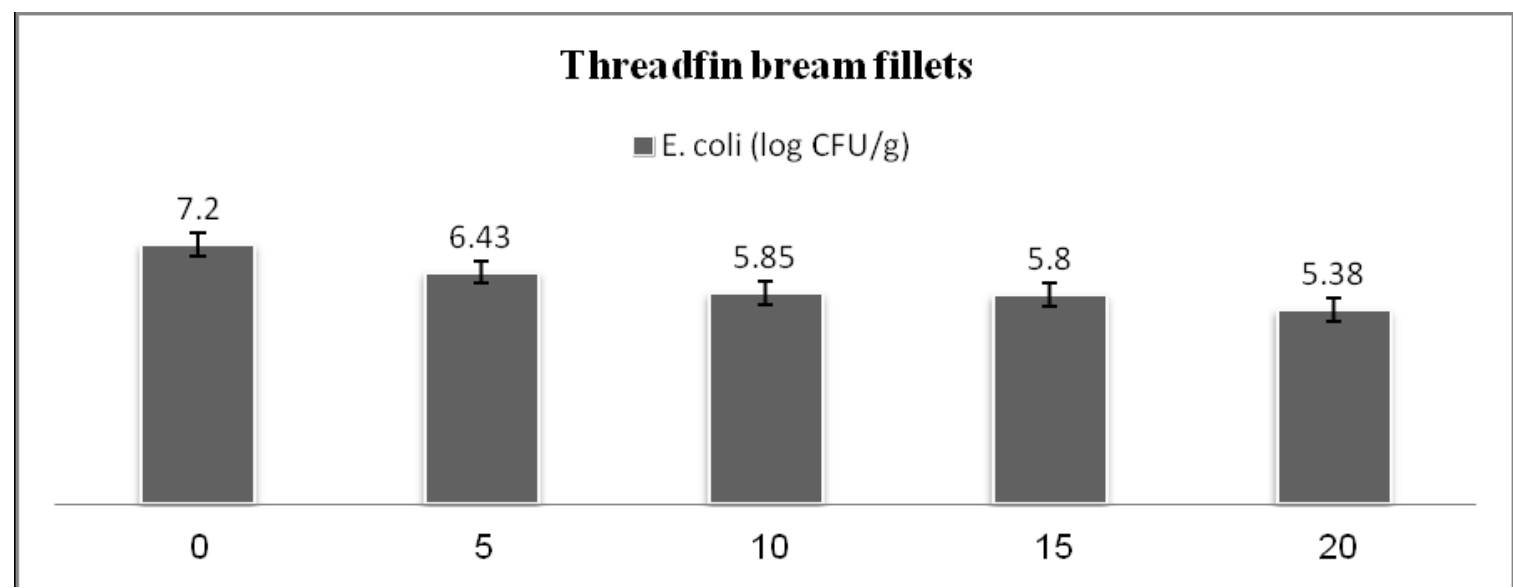

Fig. 4: Reduction rate of UV-C radiation on E. coli strain O157:H7 count (Log CFU/g) in Threadfin bream fillets for different times $(\mathrm{min})$.

UV-C irradiation reduced E. coli strain O157: H7 total count (1.82 logs $\mathrm{CFU} / \mathrm{g})$ effectively $(\mathrm{P}<0.05)$ in threadfin bream fish compared to tilapia fish fillets $(1.1 \operatorname{logs} \mathrm{CFU} / \mathrm{g})$. This might be due to the different texture of marine fish compared to fresh-water tilapia fish, and UV application is strongly influenced by surface topography. Results were different according to the surface of application as reported by Ozer and Demirci (2006). Pulsed UV-light inactivated E. coli O157:H7 on salmon fillets (1.09 $\log \mathrm{CFU} / \mathrm{g}$ ) on muscle surface for $60 \mathrm{sec}$ at $8 \mathrm{~cm}$ treatment, while, 0.86 $\log \mathrm{CFU} / \mathrm{g}$ reduction was achieved on skin surface at $5 \mathrm{~cm}$ treatment after $30 \mathrm{sec}$.

Application of UV-C radiation on different food products such as poultry and rainbow trout was reported effective for inactivating spoilage and pathogenic microorganisms (Chun et al., 2010; Haughton et al., 2011; Lázaro et al., 2013; and Rodrigues et al., 2016). UV-C wavelengths between 200 and $280 \mathrm{~nm}$ were showed germicidal activity. Whereas, wave length at $253.7 \mathrm{~nm}$ had the maximum lethal effect on microorganisms as it damaged the DNA and interrupt cell growth (Koutchma et al., 2009). UV-C radiation technology has been reported with several benefits when applied in food products (Chang et al., 1985). It is easy to implement, low cost, and do not produce any byproducts or chemical waste that might change the odor, flavor or the color of food products (Chun et al., 2009). On the other hand, Kolakowska (2003) reported the side effects as it could enhance the oxidation process by initiation of free radical oxidation and catalyzes other stages of the oxidation process. Lipid radicals, superoxide radicals, and $\mathrm{H}_{2} \mathrm{O}_{2}$ could also be formed due to UV light. Furthermore, superoxide radicals could lead to carbohydrate and protein cross linking, peroxidation of unsaturated fatty acid and protein fragmentation and degradation, and resulted in loss of membrane fluidity and functions (Koutchma et al., 2009). When UV light treatment applied in high doses, chemical changes in food composition and total product quality deterioration were obvious (Kolakowska, 2003). While using UV light treatment in moderate doses has not been associated with any adverse effects in food (Krishnamurthy 2006). Therefore, to maintain the quality and the safety of food products, the disinfection process should be properly optimized.

In this study, Maximum reduction in the total count of E. coli strain O157:H7 (1.82 logs CFU/g) in threadfin bream marine fish samples treated at $45 \mathrm{~cm}$ for 20 min. While in tilapia samples, count of $E$. coli strain $\mathrm{O} 157: \mathrm{H} 7$ was reduced to 1.1 $\operatorname{logs} \mathrm{CFU} / \mathrm{g}$ when treated at $24 \mathrm{~cm}$ for $15 \mathrm{~min}$. The treatment had different results according to the type of fish and could not achieve more than 2 logs reduction in total samples. This might be explained as the efficacy of the UV treatment for disinfecting 
fish samples influenced by other factors such as bacterial growth rate, initial bacterial population, food composition, and fish type as reported by Wright et al. (2000) and Guerrero-Beltran and Barbosa-Canovas (2004). Moreover, UV-C technique applied and concentrated on food surface, and surface irregularities could act as physical barrier against UV rays resulting in bacterial protection and survival (Morgan, 1989).

\section{CONCLUSION}

In general, by using non-thermal UV-C radiation technique, this study demonstrated that maximum reduction (1.82 logs CFU/g) of E. coli strain O157:H7 could be achieved for marine fish fillets for 20 min treatment at $45 \mathrm{~cm}$ distance, whereas $1.1 \operatorname{logs}$ CFU/g reduction for fresh water fish fillets could be achieved for 15 min treatment at 24 and $30 \mathrm{~cm}$ distances. Therefore, this study recommends that application of UV-C radiation improved the safety of marine and fresh water fish fillets.

\section{REFERENCES}

Akgün, M.P. and Ünlütürk S. (2017). Effects of ultraviolet light emitting diodes (LEDs) on microbial and enzyme inactivation of apple juice. International Journal of Food Microbiology, 260: 65-74.

Amin, H.F.; Ahmed, O.M.; Rasmey, A.M.; Younis, A.M. and Bekhit, A.A. (2018). Effect of technological processing on the safety of Indian mackerel (Rastrelliger kangurata) from Suez, Egypt. Egyptian Journal of Aquatic Biology \& Fisheries, 22(5): 273- 284.

Bank, H.L.; Schmehl, J.L. and Dratch, R.J. (1990). Bacteriocidal effectiveness of modulated UV light. Applied and Environmental Microbiology, 56: 3888-3889.

CDC (Centers for Disease Control \& Prevention) (2003). Division of bacterial \& mycotic diseases. Disease information, available at: http://www.cdc. gov/ncidod/dmbd/diseaseinfo/escherichiacoli_t.htm, accessed on 7 July 2003.

Chang, J.C.H.; Ossoff, S.F.; Lobe, D.C.; Dorfman, M.H.; Dumais, C.M.; Qualls, R.G. and Johnson, J.D. (1985). UV inactivation of pathogenic and indicator microorganisms. Applied Environmental Microbiology, 49: 1361-1365.

Chun, H.; Kim, J.; Chung, K.; Won, M. and Song, K.B. (2009). Inactivation kinetics of Listeria monocytogenes, Salmonella enterica serovar Typhimurium, and Campylobacter jejuni in ready-to-eat sliced ham using UV-C irradiation. Meat Science, 83(4): 599-603.

Chun, H.H.; Kim, J.Y.; Lee, B.D.; Yu, D.J. and Song, K.B. (2010). Effect of UV-C irradiation on the inactivation of inoculated pathogens and quality of chicken breasts during storage. Food Control 21: 276-280.

CSPI (Center for Science in the Public Interest) (2003). Seafood and produce top food poisoning culprits, available at: http://www.cspinet.org/reports/ outbreak_report. pdf, accessed on 7 July 2003.

El Zokm, G.M.; Okbah, M.A. and Younis, A.M. (2015). Assessment of Heavy Metals Pollution Using AVS-SEM and Fractionation Techniques in Edku Lagoon Sediments, Mediterranean Sea, Egypt. Journal of Environmental Science and Health, Part A, 50: 1-14.

Freitas, A.; Moldão-Martins M.; Costa H.S.; Albuquerque T.G.; Valente A. and SanchesSilva A. (2015). Effect of UV-C radiation on bioactive compounds of pineapple 
(Ananas comosus L. Merr.) by-products. Journal of the Science of Food and Agriculture, 95 (1): 44-52.

Gladyshev, M.I.; Sushchik, N.N.; Makhutova, O.N.; Glushchenko, L.A.; Rudchenko, A.E.; Makhrov, A.A.; Borovikova, E.A. and Dgebuadze, Y.Y. (2017). Fatty Acid Composition and Contents of Seven Commercial Fish Species of Genus Coregonus from Russian Subarctic Water Bodies. Journal of Lipids, 52 (12): 1033-1044.

Guerrero-Beltran, J.A. and Barbosa-Canovas, G.V. (2004). Advantages and limitations on processing foods by UV light. Journal of Food Science and Technology International, 10: 137-147.

Guerrero, R.F.; Cantos-Villar, E.; Puertas, B. and Richard, T. (2016). Correction to Daily Preharvest UV-C Light Maintains the High Stilbenoid Concentration in Grapes. Journal of Agriculture Food Chemistry, 64 (49): 9464-9470.

Haughton, P.N.; Lyng, J.G.; Cronin, D.A.; Morgan, D.J.; Fanning, S. and Whyte, P. (2011). Efficacy of UV light treatment for the microbiological decontamination of chicken, associated packaging, and contact surfaces. Journal of Food Protection, 74: 565-572.

Holck, A.L.; Liland,K.H.; Drømtorp, S.M.; Carlehög, M. and McLeod, A. (2018). Comparison of UV-C and Pulsed UV Light Treatments for Reduction of Salmonella, Listeria monocytogenes, and Enterohemorrhagic Escherichia coli on Eggs. Journal of Food Protection, 81 (1): 6-16.

Hollósy, F. (2002). Effects of ultraviolet radiation on plant cells. Micron, 33 (2): 179-197.

Jo, C.; Lee, N.Y. and Kang, H.J. (2005). Inactivation of pathogens inoculated into prepared seafood products for manufacturing kimbab, steamed rice rolled in dried seaweed, by gamma irradiation. Journal of Food Protein, 68: 396-402.

Kannapan, S. and Manja, K.S. (2004). Antagonistic efficacy of lactic acid bacteria against seafood-borne bacteria. Journal of Food Science and Technology Mysore, 41: 50-59.

Karlsen, J. D.; Krag, L.A.; Albertsen, C.M. and Frandsen, R.P. (2015). From Fishing to Fish Processing: Separation of Fish from Crustaceans in the Norway Lobster-Directed Multispecies Trawl Fishery Improves Seafood Quality. PLoS One, 10 (11): 1-20.

Kim, D.K.; Kim, S.J. and Kang D.H. (2017). Bactericidal effect of 266 to 279nm wavelength UVC-LEDs for inactivation of Gram positive and Gram negative foodborne pathogenic bacteria and yeasts. Journal of Food Research International, 97: 280-287.

Kolakowska A. (2003). Lipid oxidation in food systems. In Chemical and Functional Properties of Food Lipids, 133-168. New York: CRC Press.

Koutchma, T.; Forney, L.J. and Moraru, C.I. (2009). Ultraviolet Light in Food Technology, Principles and Applications, CRC Press, Taylor \& Francis Group, USA.

Krishnamurthy, K. (2006). Decontamination of milk and water by pulsed UV-light and infrared heating. PhD thesis. Pennsylvania State University, chapters 2: 23-44.

Lázaro, C.A.; Conte-Junior, C.A.; Cunha, F.L.; M_Arsico, E.T.; Mano, S.B. and Franco, R.M. (2013). Validation of an HPLC methodology for the identification and quantification of biogenic amines in chicken meat. Journal of Food Analytical Method, 6: 1024-1032.

LeClerc, M. and Wells, D.L. (2001). Process evaluation of an integrated model of discharge planning. Canadian Journal of Nursing Leadership, 14 (2): 19-26.

Lee, E.S.; Park, S.Y., and Ha, S.D. (2016). Effect of UV-C light on the microbial and sensory quality of seasoned dried seafood. Journal of Food Science and Technology International, 22 (3): 213-220. 
Lin, Q.; Xie,Y.; Liu, W.; Zhang, J.; Cheng, S.; Xie, X.; Guan, W. and Wang, Z. (2017). UV$\mathrm{C}$ treatment on physiological response of potato. Journal of Food Science and Technology, 54 (1): 55-61.

Martínez, O.; Rodríguez-Calleja, J. M.; Santos, J.A.; Otero, A. and García-López, M. L. (2009). Foodborne and indicator bacteria in farmed molluscan shellfish before and after depuration. Journal of Food Protection, 72 (7): 1443-1449.

Matulkova, P.; Gobin, M.; Taylor, J.; Oshin, F.; O'Connor, K. and Oliver, I. (2013). Crab meat: a novel vehicle for E. coli O157 identified in an outbreak in South West England, August 2011. Epidemiology and Infection, 141 (10):2043-2050.

Mditshwa, A.; Magwaza, L.S.; Tesfay, S.Z. and Mbili, N.C. (2017). Effect of ultraviolet irradiation on postharvest quality and composition of tomatoes: a review. Journal of Food Science and Technology,54 (10): 3025-3035.

Miller, R.; Jeffrey, W.; Mitchell, D. and Elasri, M. (1999). Bacterial responses to ultraviolet light. ASM News, 65: 534-541.

Monteiro, M.L.; Mársico, E.T.; Canto, A.C.; Costa-Lima, B.R.; Costa, M.P.; Viana, F.M.; Silva, T.J. and Conte-Junior, C.A. (2017). Impact of UV-C Light on the Fatty Acid Profile and Oxidative Stability of Nile Tilapia (Oreochromis niloticus) Fillets. Journal of Food Science, 82 (4): 1028-1036.

Morgan, R. (1989). UV green light disinfection. Journal of Dairy Industry International, 54: 33-35.

Nil, P.; Ozer, A. and Demirci, A. (2006). Inactivation of Escherichia coli O157:H7 and Listeria monocytogenes inoculated on raw salmon fillets by pulsed UV-light treatment. International Journal of Food Science and Technology, 41: 354-360.

Oviedo-Solís, C.I.; Sandoval-Salazar, C.; Lozoya-Gloria, E.; Maldonado-Aguilera, G.A.; Aguilar-Zavala, H.; Beltrán-Campos, V.; Pérez-Vázquez, V. and Ramírez-Emiliano, J. (2017). Ultraviolet light-C increases antioxidant capacity of the strawberry . Journal of Food Science and Nutrition, 5 (5): 1004-1014.

Rodrigues, B.L.; Alvares, T.S.; Sampaio, G.S.L.; Cabral, C.C.; Araujo, J.V.A.; Franco, R.M.; Mano, S.B. and Conte-Junior, C.A. (2016). Influence of vacuum and modified atmosphere packaging in combination with UV-C radiation on the shelf life of rainbow trout (Oncorhynchus mykiss) fillets. Food Control 60: 596-605.

Roy, S. (2017). Impact of UV Radiation on Genome Stability and Human Health. Advances in Experimental Medicine and Biology, 996: 207-219.

Said, T.O.; Farag, R.S.; Younis, A.M.; Shreadah, M.A. (2006). Organotin Species in Fish and Bivalves Samples Collected from the Egyptian Mediterranean Coast of Alexandria, Egypt. Bulletin of Environmental Contamination and Toxicology, 77: 451-458.

Santo, D.; Graça, A.; Nunes, C. and Quintas, C. (2018). Escherichia coli and Cronobacter sakazakii in 'Tommy Atkins' minimally processed mangos: Survival, growth and effect of UV-C and electrolyzed water. Journal of Food Microbiology, 70: 49-54.

Sheen, S.; Huang, L. and Sommers, C. (2012). Survival of Listeria monocytogenes, Escherichia coli $\mathrm{O} 157: \mathrm{H} 7$, and Salmonella spp. on catfish fillets exposed to microwave heating in a continuous mode. Journal of Food Science, 77 (8): 209-214.

Shin, J.H.; Chang, S. and Kang, D.H. (2004). Application of antimicrobial ice for reduction of foodborne pathogens (Escherichia coli O157:H7, Salmonella typhimurium, Listeria monocytogenes) on the surface of fish. Journal of Applied Microbiology, 97: 916-922. 
Shreadah, M.A.; Said, T.O., Younis, A.M.; Farag, R.S. (2006). Speciation of Organotin Compounds in Sediments of Semi-Closed Areas along the Mediterranean Coast of Alexandria," Chemistry and Ecology, 22 (5): 395-404.

Soccol, M.C.H. and Oetterer, M. (2003). Use of modified atmosphere in seafood. Brazilian Archives of Biology and Technology, 46: 569-580.

Soliman N.F.; Younis, A.M.; Elkady E.M. and Mohamedein L.I. (2018). Geochemical associations, risk assessment, and source identification of selected metals in sediments from the Suez Gulf, Egypt, Human and Ecological Risk Assessment: An International Journal, DOI: 10.1080/10807039.2018.1451301

Surendraraj, A.; Thampuran, N. and Joseph, T. C.( 2010). Molecular screening, solation, and characterization of enterohemorrhagic Escherichia coli O157:H7 from retail shrimp. Journal of Food Protection, 73 (1): 97-103.

Terajima, J.; Izumiya, H.; Iyoda, S.; Tamura, K. and Watanabe, H. (1999). Detection of a multi-prefectural E. coli O157:H7 outbreak caused by contaminated Ikura-Sushi ingestion. Japanese Journal of Infectious Diseases, 52 (2): 52-53.

Wright, J.R.; Sumner, S.S.; Hackney, C.R.; Pierson, M.D. and Zoecklein, B.W. (2000). Efficacy of ultraviolet light for reducing Escherichia coli O157:H7 in unpasteurized apple cider. Journal of Food Protection, 63: 563-567.

Wu, J.; Liu, W.; Yuan, L.; Guan, W.Q.; Brennan, C.S.; Zhang, Y.Y.; Zhang, J. and Wang, Z.D. (2017). The influence of postharvest UV-C treatment on anthocyanin biosynthesis in fresh-cut red cabbage. Scientific Reports, 7 (1): 5232.

Younis, A.M. and Nafea, S.M. (2012). Impact of Environmental Conditions on the Biodiversity of Mediterranean Sea Lagoon, Burullus Protected Area, Egypt. World Applied Sciences Journal, 19: 1423-1430.

Younis, A.M.; El-Zokm, G.M. and Okbah, M.A. (2014). Spatial Variation of Acid- Volatile Sulfide and Simultaneously Extracted Metals in Egyptian Mediterranean Sea Lagoon Sediments. Environmental Monitoring and Assessment, 186: 3567-3579.

Younis, A.M.; Soliman Y.A.; Elkady E.M. and El-Naggar M. H. (2018). Assessment of polycyclic aromatic hydrocarbons in surface sediments and some fish species from the Gulf of Suez, Egypt. Egyptian Journal of Aquatic Biology \& Fisheries, 22(4): 4959.

Younis, A.M. (2018). Environmental Impacts on Egyptian Delta Lakes' Biodiversity: A Case Study on Lake Burullus. A.M. Negm et al. (eds.), Egyptian Coastal Lakes and Wetlands: Part II - Climate Change and Biodiversity, Hdb Env Chem, DOI 10.1007/698_2017_120. 